\title{
Sustainability of Zimbabwe's Platinum Mining Sector
}

\author{
Oswell Binha \\ Africa University, College of Business Peace Leadership and Governance \\ DOI: 10.29322/IJSRP.10.12.2020.p10812 \\ http://dx.doi.org/10.29322/IJSRP.10.12.2020.p10812
}

\begin{abstract}
Sustainability of platinum Group Metals exploitation in Zimbabwe continues to be a cause for concern due to several factors. One, therefore, takes a look at factors necessary for optimum incremental beneficial mining. Prospects of mining profitability, under pinned by an enabling sustained terming of mining costs, stability in investment flows and reduced exports constraints. Mining business confidence gives better prospects for mining business growth.
\end{abstract}

Access to cheap capital, stability and dependability of fiscal policies, improved economic enablers such as electricity, transport and water, and coherence and consistency of relevant mining policies. The contribution of the PGMs sector to national GDP continues to grow. The creation of decent work and general employment remains high. This paper extrapolates performance issues in the PGMs sector and proffers possible remedies to these constraints to unlock potential Zimbabwe can enjoy. The paper further proposes linkages, both upstream and downstream, in the PGMs sector, ensuring that exploitation of this finite resource can translate to the development of other economic sectors.

Exogenous and endogenous factors influence the commitment to supporting the national mining vision and other socio-political and socio-economic questions requiring a strategic response in our quest for full-blown PGMs exploitation. Of significant concern and strategic response is the uncertainty surrounding policies on mining title, royalties and licensing and administration. To conclude, the paper shall provide direction on PGMs mining growth, profitability, investments, markets, employment and skills, and the country risk profile.

The PGMs sector responds to many interested stakeholders, and these stakeholders have varying interests. These include the shareholders, management, employees, suppliers, government and investors. What is the size of the PGMs cake in Zimbabwe? Who enjoys what quantum of the PGMs cake? Who is the largest beneficiary? Does it make economic sense for the investors to continue to grow their investment? What are potential constraints in exploiting the resource and allocating it? What is the ownership pattern of the resource? How does it compare with global best practices?

Index Terms- platinum group metals, government policy, royalties, taxation, value chains, licensing transparency

\section{INTRODUCTION}

$Z^{\text {i }}$ imbabwe's mining regime has traditionally undergone debilitating self-inflicted challenges and has threatened the viability of the entire sector. These challenges include adverse mining operating conditions resulting from lousy mining policies, weakened value chains, low economic sector linkages and a widespread negative impact of global economic conditions. Mining, as an industry, is a capital-intensive industry and requires substantial capital investments to exploit the mining resource sustainably. Attracting domestic direct investment in this sector is difficult because the local economic capacity cannot bankroll large mining projects, leaves the country to hunt for external investors capable of committing long term money into the sector.

Historically, Zimbabwe has been an envy of the world because of the wide range of quality mineral endowments in gold, diamonds, chrome, coal, copper, lithium, nickel and platinum group metals. Successful exploitation of these minerals depends on several exogenous and endogenous factors. These include a currency conundrum whose effect has increased the cost of mining over the years, crippling power shortages, unavailability of external lines of credit and offshore funding, politicised labour regime and disparaging mining, and fiscal and monetary policy regime. The sustainability of mining in Zimbabwe in general and the platinum group metals, in particular, is under the spotlight, requiring indepth evaluation.

\section{BACKGROUND TO PLATINUM MINING IN ZIMBABWE}

Platinum group metals exist in the Great Dyke of Zimbabwe and form the world's second-largest deposit only to South Africa. Historically, the Great Dyke is home to some of the most extensive mineral deposits in the same rock formations as platinum, gold, silver, asbestos, chromium, and nickel. It stretches from Northern Zimbabwe through the central parts to the southern parts of Zimbabwe. Its spans approximately 550kms.

According to Hughes, C. (1970). Lateral Cryptic Variation in the Great Dyke of Rhodesia, the great dyke was first described in 1867 by a surveyor named Karl Mauch with no information on the existence of platinum till around the 1920s. Stribrny, B., Wellmer, F., Burgath, K. et al. in their article Unconventional PGE occurrences and PGE mineralisation in the Great Dyke, metallogenic and economic aspects, the great dyke became a strategic mineral economic resource, holding base metals and PGMs of various concentrations including copper and cobalt. The geographical spread of the Great Dyke covers Darwendale, Lalapanzi, Makwiro, Mutorashanga Mvurwi, Wedza, Shurugwi and Zvishavane. Early exploitation of gold, chrome and chromite dominated mining in this area. BHP Minerals, an Australian investor who established mining operations around the Makwiro Area, spearheaded organised exploitation of PGMs in Zimbabwe. Due to complex geological and macroeconomic factors, BHP disinvested to pave the way for South African Based impala platinum. The exploitation of PGMs in oxidised surface ores, the 
potential existence of approximately 400metric tonnes of ore makes business sense for platinum producers to sink more than 5billion dollars investment over the last decade. Anglo-Americans in joint venture arrangements with Aquarius and Impala Platinum have taken advantage of the easy accessibility of this resource setting up mines in Selous, Ngezi, Shurugwi and Zvishavane.

According to the $22^{\text {nd }}$ Annual Investing in Africa Mining Indaba investment guide of 2017, four complexes hold PGMs in Zimbabwe. The biggest is the Hartley Geological Complex mined by Zimplats, holding approximately $85 \%$ of the resource. Mimosa and Unki share the remainder, with prospects of another Russian Investor, Karo Resources, potentially locating a \$4.2billion investment in the Darwendale area.

\section{RESOURCE NATIONALISATION AND VALUE CHAIN ANALYSIS IN THE PLATINUM SECTOR}

The paradox of resource endowments in Africa against stinking poverty exposes Africa state leadership. Obsession with state ownership of all strategic mining assets continues to derail practical sustainability of exploitation of these resources because states in general and the Zimbabwe government, in particular, lacks an accountable framework to eradicate opportunism and theft. The nationalisation of mineral resources has led to a resource curse in most African countries. D R Congo has persistently undergone incessant conflicts. Angola, among other highly endowed countries, remains a least developed country. Zambia is swimming in debt and continues to seek debt forgiveness against a backdrop of copper endowments of monumental proportions.

Major Players in the PGMs sector include Zimplats, Mimosa and Unki mines. A few new Russian and Chinese players have also entered the terrain intending to operate Karo Resources and Global mining. All these assets are privately owned save for the new players whose ownership is still to be disclosed. For the full-scale economic transformation of Zimbabwe, the role of government must clearly be defined. It is to create an enabling environment for private businesses to thrive. According to Gumede 2015, Zimbabwe would benefit immensely if the country moves from economic transformation to economic development. Economic development will fast track accrual of benefits to support employment creation, housing, healthcare, local enterprise development, social relation, and developed infrastructure. According to Walter Rodney 1973, the rationale of Europe under developing Africa was to exploit mineral resources to serve Europe's industrialisation. Therefore, it is imperative that the national conversation in Africa in general and Zimbabwe in particular, changes from broad-based ownership of mining assets to systematic and sustainable exploitation for economic development.

Zimbabwe boasts of being one of the top five produces of PGMs, which locates the country in a unique position to exploit platinum global value chains. According to Kapinsky @al 2002, the value chain is converting primary products from their production stages to value-added products, ensuring that these products reach the desired markets and exploiting the value chain benefits at every stage of the product development. Zimbabwe ranks second from south Africa in PGMs endowment with high levels of proven and probable reserves with a minimum mine life of 20 years. PGMs include palladium, rhodium, iridium, osmium and ruthenium. They are applied to new technological industries, among other commercial ventures.

Zimbabwe has enjoyed proceeds of organised gold and chrome mining over the years and has witnessed the formation of Mining towns such as Mhangura, Cam and Mine Motor Kadoma, Hwange, Kwekwe, and Shangani, among others, opportunities for locating the country as an African technological hub remain high. The sustainability of PGMs exploitation leads to new automotive, mobile telephony, health care, especially cancer therapy and personal hygiene, clothing and textiles, and jewellery, among other uses.

According to Anglo-American Cooperation, "A sustainable business is purposeful, competitive, resilient and agile -it is a business that thrives through both economic and social cycles" Zimbabwe needs to define its comparative advantage to competitively locate itself in global value chains in the above potential industrialisation opportunities. Trade-offs for lucrative markets, technology and relevant skills are an option to ensure local economies of scale in chosen PGMs industries. Foregoing gold mining, for example, and exchanging all gold deposits for developing local capacity to drive global platinum value chains is a crucial medium to long term economic strategy worth evaluating. Nationalisation of the resource naturally destroys all innovation in attaining smart exploitation of the PGMs because public or state-driven businesses are generally slow in decision making, bureaucratic in implementation and inefficient in cost containment. Technological innovation and digitalisation are crucial components in the future of the exploitation of mining endowments.

\section{LICENCING TRANSPARENCY IN PGMS MINING SUSTAINABILITY}

Licensing and regulations associated with setting up and operating a mining business boost appetitive for long term investments into the sector. Several questions require concise responses, particularly when it comes to state facilitation of mining licencing. What is the licensing period? How many licences does one require? Which state entities are responsible for issuing out mining licensing? Is the process of acquiring mining licensing simple enough to facilitate the speedy acquisition of the mining licence? How dispersed are the licensing authorities? What are the basic requirements for one to qualify for a mining licence? What are the associated costs of licensing?

These questions, if all satisfactorily answered, present the ease of doing business in Zimbabwe. State departments responsible for licensing vary from mining title ownership, environmental management, safety and health, use of dangerous chemicals and substances, marketing and mining operating license at the local authority level. Requirements of licensing and the process to comply with all the pre-requites to obtain some of the licences are sometimes cumbersome and repetitive, causing undue delays, frustrations, fatigue, and increased costs.

Investors, by nature, are easily intimidated if the investment compliance environment is complicated, particularly on access to critical information to facilitate mining business set-up. The consequence of this requirement is that the investor may be constrained in cash flows as they are expected to outlay compliance costs ahead of the project establishment, on its own, a 
significant budget which include the required EIA professional fees. For example, the environmental management act enforces environment impact assessments. The impact assessments are carried out by experts who engage in a broad stakeholder consultative process to avoid future conflict between the business and these stakeholders and create a collective environmental management compliance. According to the Chamber of mines, an investor receives an environment impact assessment certificate which is renewed annually. The revised policy requires the investor to pay $1.2 \%$ of the total project cost down from $10 \%$ prior to 2017. In order to promote capital inflows into the mining sector, the Chamber of Mines (COMZ) recommends the reduction of EIA fees to a rate of $0,5 \%$ of project cost with an upper limit of US\$10 000 , in line with regional best practice". The Mining representative organisation specified that "The Environmental Impact Assessment (EIA) fee at $0,8 \%$ to $1,2 \%$ of project cost with a cap of US\$2 million remains high. Investors are discouraged from discouraging the execution of investment projects in the mining industry.

Further, all local authorities are expected to license all businesses in their local areas again. PGMs mining, as a business, derive their social license to operate by ensuring they embrace not only the local authority licensing requirements but also accept informal social engagements with the local community structures. While the costs associated with formal or informal engagement with local community leaders are minimal, local authority processes are generally a repetition of the EIA process. It is, therefore, an unnecessary compliance process that should be integrated into the EIA process for simplicity.

Mining uses significant amounts of water. Water management legislation requires mining companies to obtain water management licencing. The use of substances such as explosives, processing plant chemicals and mining residue management require separate licencing. One, therefore, expects that all these licensing responsibilities be carried out under one roof by a single government agency.

According to Tralac, (Trade Law Centre of South Africa) "the Zimbabwe Investment Development Agency Act [Chapter 14:37] (ZIDA Act) (1.98 MB), ZIDA Act, deals with the promotion, entry, facilitation and protection of investment in Zimbabwe. The act was introduced as part of the government's efforts to streamline investment laws and create a businessfriendly environment attractive to both local and foreign investors" the world bank group through IFC advises that Subnational political entities, whether states, provinces, regional governments or municipalities, play a central role in fostering a sound business climate. While Zimbabwe Government's effort to create ZIDA is commendable, the institution has maintained its inherent traditional inefficiencies symptomatic of the parent agencies, the one-stop investment centre, Zimtrade and Zimbabwe special economic zones authority. The consequences of ineffective, excessive or, in some instances, inappropriate regulation generally have adverse effects on investment and economic development. The promotion of a simplified but sophisticated investment environment presents a clear pedestal for business innovation, certainty and coherence, particularly in PGMs mining because the sector is not only sophisticated highly capital intensive. Creating an appropriate well-regulated

This publication is licensed under Creative Commons Attribution CC BY

http://dx.doi.org/10.29322/IJSRP.10.12.2020.p10812 investment climate naturally attracts long-term money, which is a development prerogative for positive economic outcomes.

The IFC further underscored the need for integrity in instituting simplified business climate processes and procedures by eliminating investment regulation and licensing impediments. Corruption, vice and institutionalised graft are offshoots of constraints associated with complying with bad laws, guidelines and procedures.

Issuing mining licences "entitle the holder to prospect, peg and register claims in terms of the act. An exclusive prospecting order confers exclusive rights to prospect for specified minerals in any identified location within Zimbabwe" ICLG 2018. Expropriation of platinum-bearing mine concession originally owned by Zimplats and offered to Karo Resources, a project expected to create a \$4.2-billion mine, has further negatively affected Zimbabwe's property rights record. Whilst Zimplats had no choice but to cede approximately 24000 ha of the company's land to the state, the transaction has been misunderstood to be evidence of the state reneging on earlier investment agreements entered into by investors.

Licensing, therefore, plays a crucial role in the sustainability of PGMs exploitation in Zimbabwe. Insulating the licensing regime from the vagaries of political manipulation, enforcement of populist policy decisions which may affect existing agreements and ill-thought regulatory changes will deal a fatal blow to future investment potential, particularly in cases of wholesome reversals of agreements previously entered into between the state and external investors.

\section{THE MINING EXPLORATION FOR SUSTAINABLE MINING}

A compelling PGMs mining investment depends on the availability of the mining resource, the availability of skills to extract the resource and the return on investment. Whilst the above is necessary for deciding to invest, a conducive macro-economic environment in broad terms is a catalyst to establishing a mining venture. The gestation of a mining project is long term, and longterm investments by nature require long term money. Policy clarity is a necessity and sufficient to enhance attracting investment into the PGMs sector.

The mines and minerals Act in Zimbabwe recognises ownership of mining assets called claims, special mining grants, and mining leases. Property rights are equally central to guarantee ownership of mining assets targeted and must be observed as a precondition to attract capital in mining exploration. Mining exploration budgets are called sunk budgets. Zimbabwe currently exploits four known platinum ore deposits, all found in the great dyke.

Zimbabwe is currently underexplored. General negative perception that Zimbabwe has an awkward mining title management system, characterised by difficulties in applying the system, old and easily manipulatable, militates against the ability of the country to attract both internal and external exploration money. Lethargy and resistance to computerise mining title management systems are misunderstood to harbour institutionalised corruption, hence the continued existence of mining title conflicts beyond the PGMs sector. The Discovery of any minerals has primarily been from old workings, culminating in historical geological information rather than virgin land with no 
known exploration history. Advanced exploration techniques will shape the future of exploration work in Zimbabwe, particularly where private exploration companies are engaged.

Conditions sufficient for attracting the most reputable exploration firms include harmonising the role of the state in the exploration process. The risk appetite and averseness for exploration financing depend primarily on the country risk profile, particularly with high-value metals such as platinum. The exploration phase is the mineral discovery phase with the potential

\section{Distribution of PGMs Value}

\section{Table 1}

\begin{tabular}{|c|c|}
\hline 3 Year Period to June 302015 & $(0000)$ \\
\hline Export proceeds & 2713360 \\
\hline Payments & \\
\hline Local Suppliers & 893401 \\
\hline Employees & 425270 \\
\hline Government - duty, royalties and taxes & 400325 \\
\hline CSR \& Community Trust & 27462 \\
\hline Capital Expenditure - Local & 503084 \\
\hline Foreign Suppliers & 509627 \\
\hline Interest Paid & 34693 \\
\hline Loan Repayment & 206881 \\
\hline Dividends & 86000 \\
\hline $\begin{array}{l}\text { Platinum Production and shared benefits (2012- } \\
\qquad \text { 2015) }\end{array}$ & $3,086,743$ \\
\hline
\end{tabular}

Source: Zimbabwe Platinum Producers Association to generate relative value. It takes an average of 10-15years to explore, discover, engage in a prestart up feasibility assessment and engage in full-scale mining. Exploration policy incentives, whether legal, fiscal, regulatory and monetary, take into account

\section{The policy consistency, coherence and complementarity} potential huge losses associated with this process. 
Figure 1

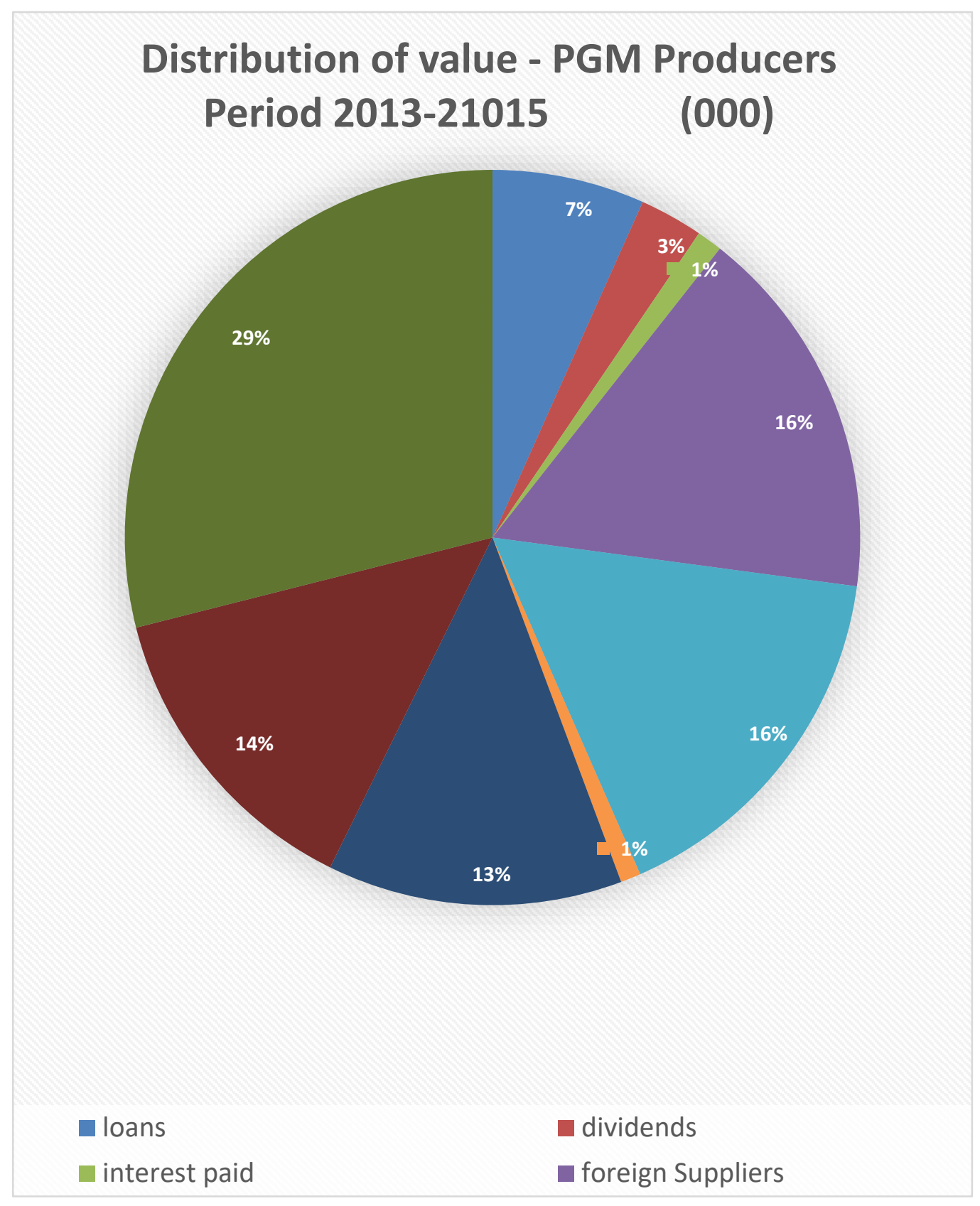




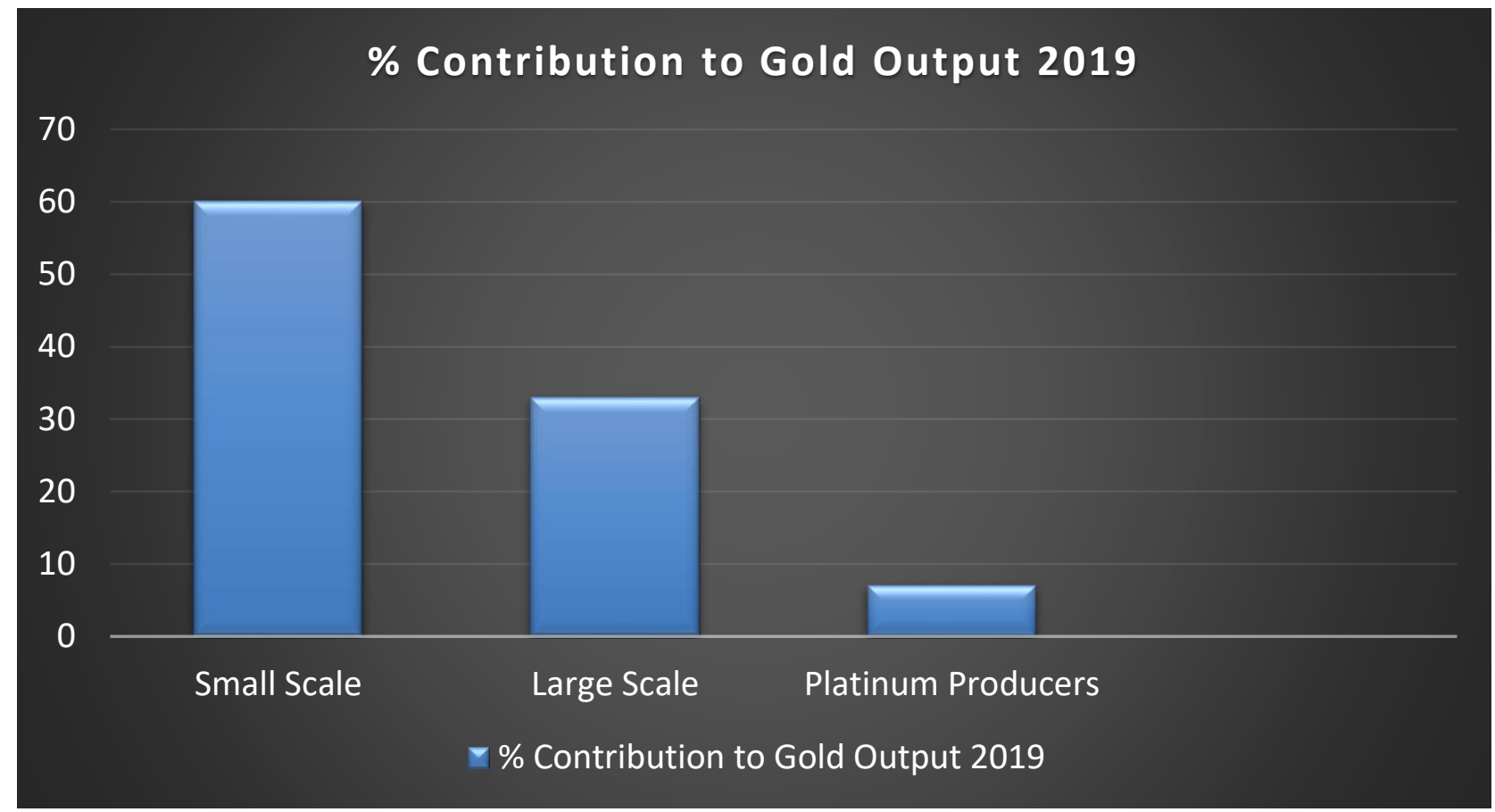

Diagram 1

Source: Chamber of Mines Q1 Journal

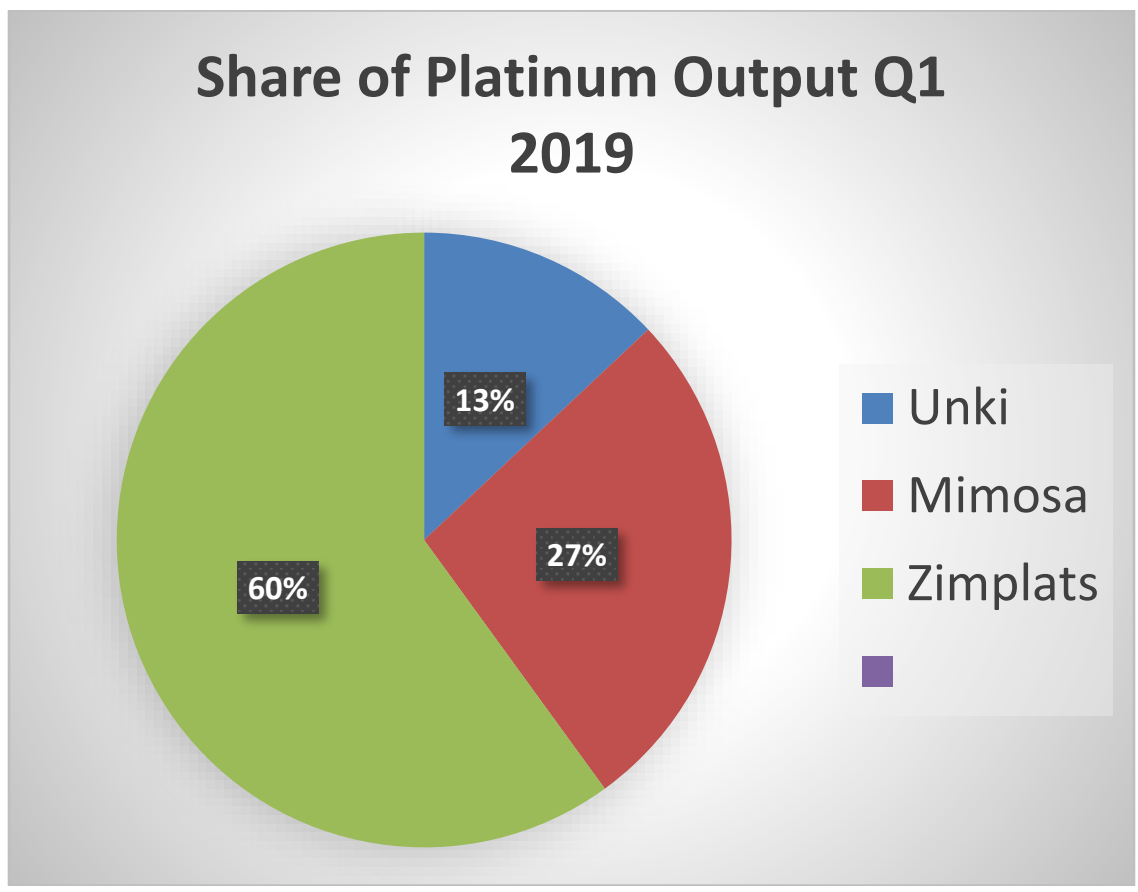

Source: Chamber of Mines Journal

The prominence of artisanal mining demonstrates a catastrophic failure of Zimbabwe's mining policy. The unintended consequences are the obtaining high company mortality rate of organised gold producers, capital flight, disinvestment, and reduced capacity utilisation among the few surviving mining companies - none of the studied public policy theories best suit Zimbabwe's policy development architecture. Simply put, public policymaking postulates the construction of a set of processes, procedures and systems to enhance optimal management of public assets. Policymaking invites a multiplicity of stakeholder interests. According to the garbage-can theory, these interests cut across inside and outside government. The systems theory of public policymaking further includes individuals, special interest groups, and countries depending on the problem at hand.

According to the Chamber of Mines, policy dialogue between existing mining operators remains "suboptimal" Emerging issues affecting existing mining investments include a complicated legislative regime, a more complicated fiscal and 
monetary regime, and an even more complicated foreign exchange management regime. Mining operators are uncompetitive, with very low opportunities to access low-cost capital and coupled with uncertainty on continued ownership of existing mining titles. Volatilities of exchange rates against major currencies, punitive surrender requirements and the blanket enforcement of the $2 \%$ electronic money transfer tax are part of a basket of complex policies the PGMs sector grappling with conformance.

Therefore, the role of government policy in sustainable mining in Zimbabwe is to give direction to citizens, corporate or individual, providing them with leadership in optimum exploitation of platinum resources and their by-products. The basket of preferred policies must be complementary, coherent and consistent. Fiscal and monetary policies by nature give impetus to mining and exploration policies, resulting in creating a competitive mining environment that attracts the best and globally reputable extractors.

Sustainable mining thrives where mining returns are promising. Reporting and collating mining returns is a collective responsibility of the mining companies and various government and quasi-government arms in Zimbabwe. These include monetary authorities regulated by the Reserve bank act, Fiscal authority overseen by the finance act and a multiplicity of regulators such as mines and minerals cooperation of Zimbabwe (MMCZ), Environmental Management Agencies (EMA) and the parent ministry borne by the mines and minerals act. Whilst the national aspiration in exploiting PGMs in Zimbabwe is to create sustainable mining for the country's benefit, operations of all state entities involved in the sustainability of PGMs mining run contrary. Fragrant disregard of the laws and policies is consequentially disastrous, mainly when the intention is to develop a comprehensive PGMs sector development plan.

Figure 1 above shows the distribution of the value of PGMs from the year 2012 to 2015 . A brief analysis of the given statistics shows that a combined $83 \%$ of the total value is accumulating to the state, local suppliers' government, communities and employees. The PGMs value proposition is accruing to Zimbabwe. The declared dividend for the period under review is a paltry $3 \%$ of the 3billion dollars. Local suppliers received approximately $45 \%$ of the value. $27 \%$ of the value is external, comprising of loans repayments and loan interests, foreign suppliers, and declared dividends to those shareholders who may be residents outside Zimbabwe. The PGMs sector also contributes significantly to the annual national Gold Output, as indicated in diagram 1.

The sustainability matrix in the PGMs sector, therefore, should aspire to:

1. Contribute to Broad infrastructure development social cohesion related infrastructure responding the justification of obtaining their social licences to operate in the relevant communities. Infrastructure empowers local communities. Food security, education and human security are natural benefits accruing from infrastructure development. PGMs are a finite resource. Ensuring that the proceeds accruing from exploitation of this resource contributes to creating reliable energy and power, water bodies, roads and rail, among other critical infrastructure needs, is strategically important.
2. Industrialisation - the creation of new industries, local enterprise development, forward and backward linkages, sustainable economic enabler supply-side related industries and support of community-based projects.

3. Human capital Development and employment Creation - the availability of dedicated mining skills, development of a framework to support PGMs sectors and its linkages such as engineering, human resources, exploration, processing and marketing, and creation of formal employment nationwide.

4. Create value for the investors - investors are motivated to increase investment capacity if the return on the investment is attractive. A combination of progressive public policy mix and recruitment of globally reputable mining operators leads to the development of mining towns nationwide. The growth of Zvishavane, Shurugwi and Ngezi are cases in point.

5. Contribution to government fiscus - progressive economies survive on rationale taxation of economic players. Expropriative and exploitative policies scare away good investors. Governments are not competitors to economic players but fluid facilitators of economic activity, results of which are a broader base to collect direct and indirect taxes. Where policies are conduits to erode investor value, discourage honest work, reward corruption and theft and create institutionalised economic inefficiencies, the result is investor flight.

The mineral beneficiation, value addition and industrialisation

Zimbabwe, like many countries in Africa, does not derive benefit from manufactured mining exports. All mining exports are exported as primary products. In PGMs, all three mines operate underground mines, extracting over and above the PGMs, gold, platinum, palladium, rhodium nickel-copper, iridium and ruthenium.

Zimbabwe has no installed capacity for mineral beneficiation save for three-stage processing. Platinum mines extract the rock and convey it as bulky ore to the process plant, where it undergoes crushing and granulation to pulp. This pulp underscores further milling and smelting, in the case of Zimplats and Unki, to mate. The mate is the combination of all the minerals mentioned above ready for export. According to Anglo American Cooperation, Major PGM mining integrates mining, refining, and maintaining considerable processing assets that produce refined PGMs and by-products. Zimbabwe's existing infrastructure can Mine, Concentrate, and Smelt. Refining and Fabrication facilities do not exist hence the export of mate.

For sustainability of the PGMs sector, Zimbabwe has an exceptional opportunity to create conditions for the growth of existing PGMs and design a deliberate framework to attract more prominent investors in the sector. Refining and fabrication to produce final products depend on economies of scale. To move the country towards complete beneficiation of PGMs:

1. Role clarity is critical. Mining companies need the capacity to increase rock extraction and processing, as indicated in figure 2 below. This capacity justifies the development of refining and fabrication capacity. 
2. Government must deliberately engage stakeholders in mining, finance, investments, potential markets to secure necessary guidance on establishing inward to outward Platinum Group Metals value chains. Establishing special economic zones to attract investment into automobile industries, healthcare delivery, technologies, and other global value chains. Genuine stakeholder consultations and necessary assurances and commitments to the rule of law, property rights, profits repatriation may assist in regaining lost trust and confidence from economic players.

3. Specialisation may be a recommended starting point given potential integration with Zimbabwe's traditional markets in the E.U. and America. Whilst the opportunities are a wide selection of a few areas of specialisation demonstrates the organisational capacity for the country to pursue coordinated industrialisation.

4. Robust ease of doing business package to support PGMS industrialisation is necessary to establish centres of excellence, particularly in local areas where the mining is undertaken.
5. Availability of statutory incentives, guarantees, and realigning taxation and royalties with global best practices may incentivise potential investors to consider Zimbabwe as a stable base to establish industries.

6. Government to encourage linkages and partnerships between local Zimbabweans and potential foreign investors to ensure knowledge and skills exchange.

7. Define a consistent framework to package the government of Zimbabwe intention to achieve a 12billion-dollar mining industry by 2030 . This will call the government to unlearn many current uneconomic decisions they have pursued late, such as suffocating businesses of the much-needed foreign exchange through crippling foreign currency retention, liquidation, and surrender policies. Deliberate effort to fix mining industry capacity constraints, a massive gap in mining industry infrastructure, particularly power shortages, may assist in turning around the mining sector beyond 2021 .

8.

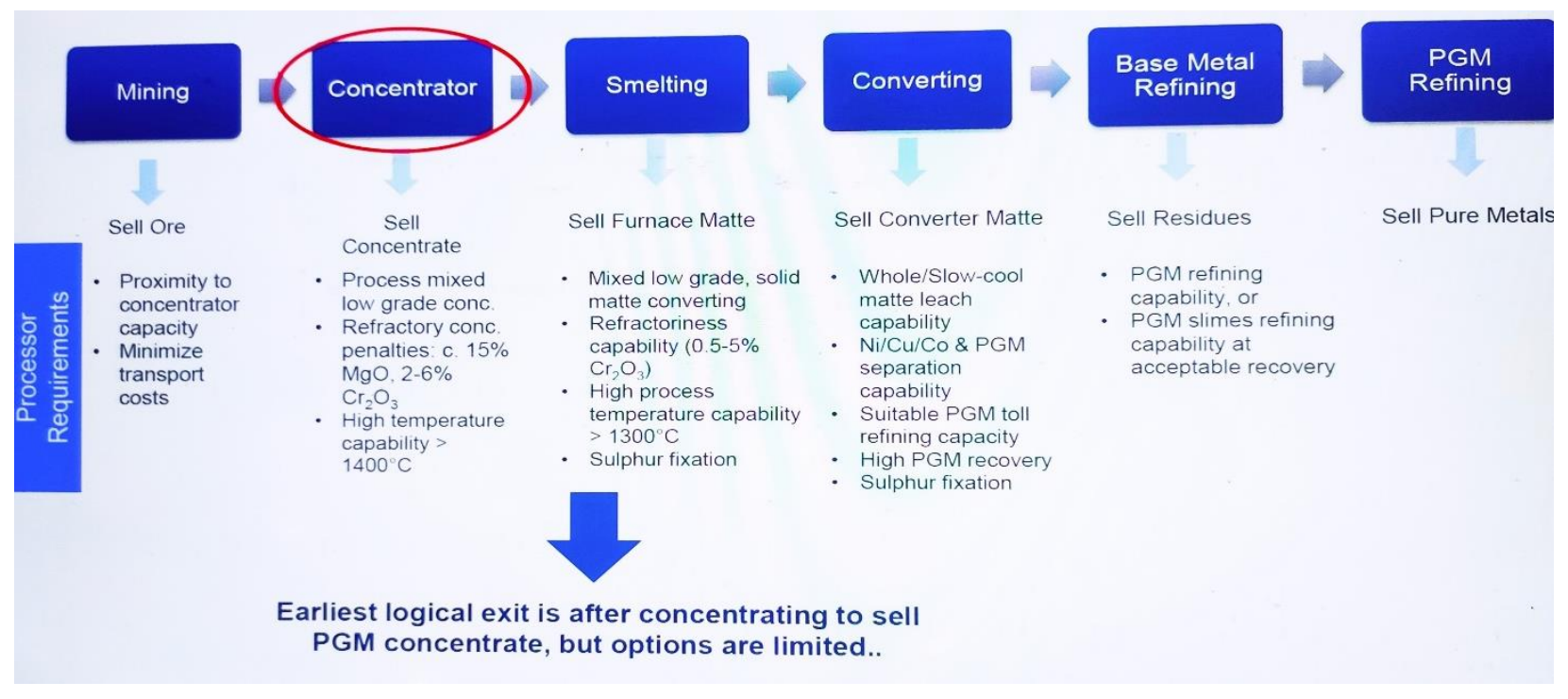

\section{The rationale of royalties and taxation}

Globally, mining sector realignment was necessary mainly when global best practices turned to fix royalties and taxation regimes as low hanging fruit. Mining policies and regulations have modelled mining taxation to ensure mining sector contribution to national economic growth, particularly in large scale mining. Some countries have gone further to implement fiscal decentralisation of mining. Local governments are empowered to levy some taxes while the central government also enforce other taxes.

Royalties are a form of government tax generally agreed between the government and the mining investor. The "economics of platinum mining" provides a base for the calculation of royalties' thresholds. There are varied royalty categories, and those applicable in the platinum mining sector consider the fiscal needs of the government, communities, and local authorities. The interest of the investor, sustainability plans and indeed global best practices are taken into consideration.

PGMs sector in Zimbabwe remains affected by the uncertainty surrounding royalties and taxation, particularly as the national resource ownership conversation has undergone widespread misinterpretation. The geopolitical terrain continues to suffocate strategic planning of the PGMs sector because national politics' obsession with ownership of all productive assets continues to grow. The adage that "owning 50\% of an elephant is far better than owning $100 \%$ of a rat" has found no space in strategic mining economics in Zimbabwe.

Concerns of opaqueness and lack of transparency in managing royalties and related fiscal taxation of mining assets in Zimbabwe explain low long-term investment levels in the sector, particularly in the last decade. Whilst Russia and China have since expressed interest in the sector; there is general lethargy and dragging of feet in fully establishing themselves. 


\section{Fiscal Methods and Their Amenability to Fiscal Decentralisation}

\begin{tabular}{|c|c|c|c|}
\hline Tax type & $\begin{array}{l}\text { National } \\
\text { Govt }\end{array}$ & $\begin{array}{l}\text { Provincial } \\
\text { Govt }\end{array}$ & $\begin{array}{l}\text { Local } \\
\text { Govt }\end{array}$ \\
\hline $\begin{array}{ll}\text { Incomes } & \text { or } \\
\text { profit-based } & \\
\text { taxes } & \\
\end{array}$ & Applicable & $\begin{array}{l}\text { Partially } \\
\text { Applicable }\end{array}$ & $\begin{array}{l}\text { Not } \\
\text { Applicable }\end{array}$ \\
\hline Import duty & Applicable & $\begin{array}{l}\text { Not } \\
\text { Applicable }\end{array}$ & $\begin{array}{l}\text { Not } \\
\text { Applicable }\end{array}$ \\
\hline Export duty & Applicable & $\begin{array}{l}\text { Not } \\
\text { Applicable }\end{array}$ & $\begin{array}{l}\text { Not } \\
\text { Applicable }\end{array}$ \\
\hline $\begin{array}{l}\text { Royalty (profit- } \\
\text { based type) }\end{array}$ & Applicable & $\begin{array}{l}\text { Partially } \\
\text { Applicable }\end{array}$ & $\begin{array}{l}\text { Not } \\
\text { Applicable }\end{array}$ \\
\hline $\begin{array}{l}\text { Royalty (ad } \\
\text { valorem type) }\end{array}$ & Applicable & Applicable & $\begin{array}{l}\text { Partially } \\
\text { Applicable }\end{array}$ \\
\hline $\begin{array}{l}\text { Royalty tax (unit } \\
\text { type) }\end{array}$ & Applicable & Applicable & Applicable \\
\hline $\begin{array}{l}\text { Royalty tax } \\
\text { collected } \\
\text { nationally and \% } \\
\text { distributed } \\
\end{array}$ & Applicable & Applicable & Applicable \\
\hline Licensing fees & Applicable & Applicable & Applicable \\
\hline $\begin{array}{l}\text { Surface rental or } \\
\text { land use fees }\end{array}$ & Applicable & Applicable & Applicable \\
\hline $\begin{array}{l}\text { Withholding } \\
\text { taxes on loan } \\
\text { interest, } \\
\text { dividends, } \\
\text { services }\end{array}$ & Applicable & $\begin{array}{l}\text { Not } \\
\text { Applicable }\end{array}$ & $\begin{array}{l}\text { Not } \\
\text { Applicable }\end{array}$ \\
\hline $\begin{array}{l}\text { VAT on goods } \\
\text { and services }\end{array}$ & Applicable & $\begin{array}{l}\text { Partially } \\
\text { Applicable }\end{array}$ & $\begin{array}{l}\text { Not } \\
\text { Applicable }\end{array}$ \\
\hline $\begin{array}{l}\text { Sales \& excise } \\
\text { tax }\end{array}$ & Applicable & $\begin{array}{l}\text { Partially } \\
\text { Applicable }\end{array}$ & $\begin{array}{l}\text { Partially } \\
\text { Applicable }\end{array}$ \\
\hline Stamp duty & Applicable & Applicable & Applicable \\
\hline $\begin{array}{l}\text { Property tax (on } \\
\text { a book or } \\
\text { assessed value) }\end{array}$ & Applicable & Applicable & Applicable \\
\hline $\begin{array}{l}\text { Payroll based } \\
\text { taxes }\end{array}$ & $\begin{array}{l}\text { Partially } \\
\text { Applicable }\end{array}$ & $\begin{array}{l}\text { Partially } \\
\text { Applicable }\end{array}$ & $\begin{array}{l}\text { Not } \\
\text { Applicable }\end{array}$ \\
\hline Surtaxes & Applicable & Applicable & Applicable \\
\hline User fees & Applicable & Applicable & Applicable \\
\hline & & & \\
\hline
\end{tabular}

Source: The World Bank Group Mining Department

Incomes and profit-based taxes are more user-friendly to apply and legislate; therefore, it is a commonly used taxation method. The method hardly credences the provincial and local governments' revenue collection requirements but allows the central government to perform an allocative function. According to Prof Professor James M., Otto setting the tax rate and setting the rules for determining the taxable income base will be subject to the determined tax rate. He further argues that the tax is best suited to implementation at the national level because of the complexity in balancing taxable revenues and allowed deductible costs.

The sustainable and optimum royalties and taxation model for Zimbabwe in the PGMs sector would take into account:

1. The national aspiration of growing the sector to 12billion dollars

2. The empowerment of communities and deregulation of state authority

3. Local procurement and local enterprise development

4. Creation of all forms of infrastructure

5. Global Value chain development and industrial linkages

It, therefore, requires that Zimbabwe drastically reduces royalties and considers Royalty ad valorem type tax. Further, a flat, low rate of Incomes or profit-based taxes be instituted, including scarping of any forms of export duties. Incentives, value creation, the empowerment of communities, Local procurement and local enterprise development, creation of all forms of infrastructure that enhances social cohesion, facilitate Creation of Global Value chains and industrial linkages.

\section{The state ownership question?}

The Zimbabwe story of state ownership of productive assets leaves an aftertaste. The state owns the most extensive mining portfolio in gold, diamonds, coal, iron, and steel in the mining sector alone. Whilst the ownership on paper is attractive, these assets are the worst-performing.

Under complete information, the early contribution by Barone (1908) proved the equivalence between the two ownership modes. More recently, Sappington and Stiglitz (1987) extended the equivalence result under asymmetric information. However, the setting and the stringent assumptions under which the result holds, which include the possibility to enforce complete contracts, are hardly met in real world cases. This make the theoretical framework of limited practical relevance in the case of developing countries, where privatisation and regulation opportunities are far from meeting these stringent conditions, since contracting opportunities may be severely limited, many events, risks and choices can hardly be ex-ante fully anticipated, so that are not likely to be described and then enforced in contracts. Accordingly, practical approaches should be developed to take into account of informational and incentive issues, especially in the area of implementation. Yet, little work has been done beyond the normative assumptions, neglecting the relevant implementation issues.

Source: Vagliasindi (2007)

\section{The broad indigenisation and economic} empowerment

Promulgation of the indigenisation and economic empowerment act, driven by political interest, incorporated aspects of equity ceding by foreign companies to facilitate equity ownership by locals in those foreign-owned companies and community participation through community share ownership schemes.

According to Herbert Smith Freehills LLP - James Watson, Rebecca Major and Jerome Hamilton, A statutory instrument was published in the Zimbabwean Government Gazette on March 25 
2011 (the "Statutory Instrument"). The Statutory Instrument's primary provision is to compel mining companies with a net asset value of or above US\$1.00 (rather than companies with an asset value of or above US\$500,000 as set out in the Regulations) operating in the country to:

submit indigenisation implementation plans to the Minister within 45 days of the Statutory Instrument's gazettal, i.e., May 9, 2011, and dispose of $51 \%$ of their shares to indigenous Zimbabweans by September 252011.

An indigenisation and economic empowerment fund was created purportedly to assist indigenous Zimbabweans in acquiring equity in foreign-owned companies. The statutory instrument was opaque, vague and unreasonable at law and exposed the government to legal challenges that would derail the entire program. Their integrity is questioned where statutory instruments are used because they are executive promulgations made without parliament approval. The whole program was reversed by 2017 as the costs of further implementation were outweighed by the benefits of discontinuing it.

\section{THE CORPORATE GOVERNANCE AND ACCOUNTABILITY INQUIRY}

Demand for quality corporate governance in both public and private companies cannot be overemphasised. Institutional investors take great care in assessing the quality of boards running with critical national assets globally, ensuring that those fund managers and investment giants provide critical investment guidance. Sustainability of Zimbabwe Platinum mining sector is guaranteed when:

- Investors are sure and confident in corporate culture, strength and independence of national institutions, and the dependability of investment policy regime.

- Lawmakers acknowledge that Mining investment requires long term money and is capital intensive. The integrity of legal and regulatory principles and systems has a knock-on effect on the ability of investors to forward cast their future earnings and return on investment.

- Corporate governance enforcement safeguards robust performance of company boards, ensuring that their oversight role is not interfered with, accommodates diversity, provide for reasonable executive compensation, knowledge and skills exchange and enhance the sustainable growth of the investor's portfolio

According to Impala platinum, Sound corporate governance is a critical foundation for protecting stakeholder value and achieving the group's strategic growth objectives. The company's governance universe demonstrates how the pillars of value are governed through their four governance segments: the board, finance, risk, and social and sustainability in support of the organisation's strategy and purpose. The elements in each segment are governed with appropriate processes, systems and resources to ensure the company demonstrate the desired governance outcomes. Impala Platinum is one of the critical and strategic players in PGMs exploitation in both Zimbabwe and South Africa. Does Zimbabwe provide an optimum environment for sufficient demonstration of correct corporate governance and accountability? Promulgation and implementation of the indigenisation and economic empowerment legislation laid bare the suspicion that Zimbabwe is incapable of creating robust corporate governance structures. Whilst one would argue that two key processes were undertaken to give effect and credence to this aspect, none of the two has been implemented in later and spirit. The parastatals corporate governance legislation and the Zimcode fall short of the necessary and sufficient requirements for enforcement of good corporate governance practices.

A Case between the Zimbabwe government and Zimbabwe Platinum Mines wherein Zimplats lost part of its resource to Karo Resources continues to question the integrity of the Zimbabwean government, particularly where respecting and honouring agreements is concerned. Commit to transparency. Dr Nicole Bieske, Head of Program - Mining for Sustainable Development, Transparency International, Governments should set clear, transparent and effective rules and criteria for mining approvals processes, and they should enable the public to access this information. Companies should be transparent about their operations, including their subsidiaries, joint venture partners and where they operate. They should also disclose their project rights and obligations, including contracts, licenses, environmental and social impact and management plans. The potential for conflict of interest between government employees, political institutions and mine operators must be eradicated.

Governments and Companies should continuously function with integrity ensuring rigid legal and regulatory frameworks are adhered to.

\section{The PGMs mining best practice}

Mining Policy Framework (2003) identified as best practice for exercising good governance of the mining sector and promoting the generation and equitable sharing of benefits to contribute to sustainable development. These best practices are divided into six key pillars: the legal and policy framework; financial benefit optimisation; socio-economic benefit optimisation; environmental management; mine closure and the post-mining transition; and artisanal and small-scale mining. PGM has strived to show good practice over the years in most countries through corporate programmes that cover the following areas Supply chain development, Employment, Local business development, Regional development, Infrastructure

South Africa is the world's largest producer of platinum, processing 110mt in 2018. The country's reserves of platinum group metals (PGMs) stand at 63,000mt. The significance of the Platinum mining industry to the economy of South Africa is reasonably well acknowledged. PGMS in South Africa has played a vital role in the economy's evolution positioning South Africa in the world. The South African PGM mining has undergone a remarkable transformation from essentially exporting raw minerals to establishing value-addition facilities (mineral processing and manufacturing). This transition has partly resulted in several large-scale resource-based investment projects, such as Columbus Stainless Steel, Saldanha Steel, Lion Ferrochrome 
smelter and others. This demonstrates the country's state of readiness for value addition.

PGM in South Africa has elevated local suppliers to reduce imports, created development zones in South Africa, and reduced reliance on mining through local and economic development. The PGM has invested in infrastructure, especially roads and water purification facilities for their mines.

Forward and backward linkages are essential in the mining and minerals sector. Mineral resources present great potentials for sustainable economic growth and development (Mahonye and Mandishara, 2015). Given the above, South Africa exploits their resources for higher growth rates, technological transfer, and poverty alleviation and increases per-capita welfare. The South African manufacturing industry, which is now a significant contributor to national income, owes its origin to the mining industry's needs.

PGM mining has drawn people out of the agricultural sector into commerce. The higher concentration of people in such areas together with an improved transport system facilitated the establishment of various factories orts, banking facilities, schools, libraries, hospitals, theatres, and many other services. It also facilitated the establishment and expansion of towns, thus creating new and more accessible markets for agricultural products, construction of railways and roads, and so forth. Mining, therefore, stimulate the agricultural, manufacturing, and even tertiary sectors.

The Russian economy has developed better than expected in recent years, and the prospects for the coming years are rated as generally good due to its leading role in the mining of platinum group metals. Russia is the second-largest producer of platinum in the world, with a 2018 production of $21 \mathrm{mt}$. The country's reserves of PGMs are 3,900mt (U.S. Geological Survey.) the PGM is highly consolidated. The Strategic Investments Law, which regulates foreign investors' access to the mining industry, gives Russian companies that play critical roles in the sector and restricts foreign firms from developing large or 'strategic' deposits.

In Russia, PGM companies invest many resources in exploration and production facilities and look at recycling processes and procedures to ensure the continued future supply of these essential metals.

Canada takes the fourth spot in the list of global platinum recovery, with a production of $9.5 \mathrm{mt}$ last year. A significant part of platinum mined in the North American country is a by-product of nickel mining. The country's reserves of PGMs are $310 \mathrm{mt}$. Canada exports the majority of its output to the U.S.

Mining generates the much-needed revenue and raw materials required for industrial development (International
Council on Mining and Metals (ICMM), 2014). PGM mining generates the much-required capital to develop other vital sectors of the economy, thus helping to address the problems of unemployment, poverty, and inequality in Canada

The US is the fifth largest platinum producer globally, with a production of $3.6 \mathrm{mt}$ in 2018 . The country owns two platinum producing mines, including the Stillwater Mine, located in Nye, Montana, and the East Boulder Mine, located by Big Timber, Montana. The modernisation of the PGM industry in America is helping in ensuring global competitiveness and future sustainability. Through collaborative partnerships between PGMs and other stakeholders, the United States of America has managed to shape an industry that is safer, more sustainable and efficient, and better harmonised with the needs of communities and society as a whole.

\section{OPTIMUM PGMS SUSTAINABILITY MODEL FOR ZIMBABWE}

Creating optimum macroeconomic conditions, eradicating political and other risks, and engendering a robust mining framework is the panacea to developing sustainable PGMs mining. The illustration below demonstrates the potential the country currently possesses for full-scale development of the PGMs sector. This illustration comforts all the benefactors and beneficiaries of the value accruing from optimum exploitation of the PGMs in Zimbabwe. It adequately captures all interests associated with the existence of the PGMs in Zimbabwe. Role clarity is therefore critical in ensuring ease of exploitation of the resource. The PGMs sector can grow from the current 3-3.5billion-dollar industry to 20billion dollars only if we avoid losing value along the entire value chain. The state need not obsess with owning any of the resources but create optimum conditions for retaining all the value and proceeds of exploiting the resource in Zimbabwe through value addition and beneficiation, dedicated infrastructure development, industrialisation, linkages, and local enterprise, as well as value chain development.

Whilst the current value distribution of the PGMs is more than $80 \%$, the proposed model will broaden the expected output from the current 3billion dollars. Derivatives from value accumulation of beneficiation and industrialisation will provide a multiplier effect at every stage of beneficiation. Feeder and support industries are created with the potential to harness expertise, innovation and skills to enhance downstream and upstream support industries. 


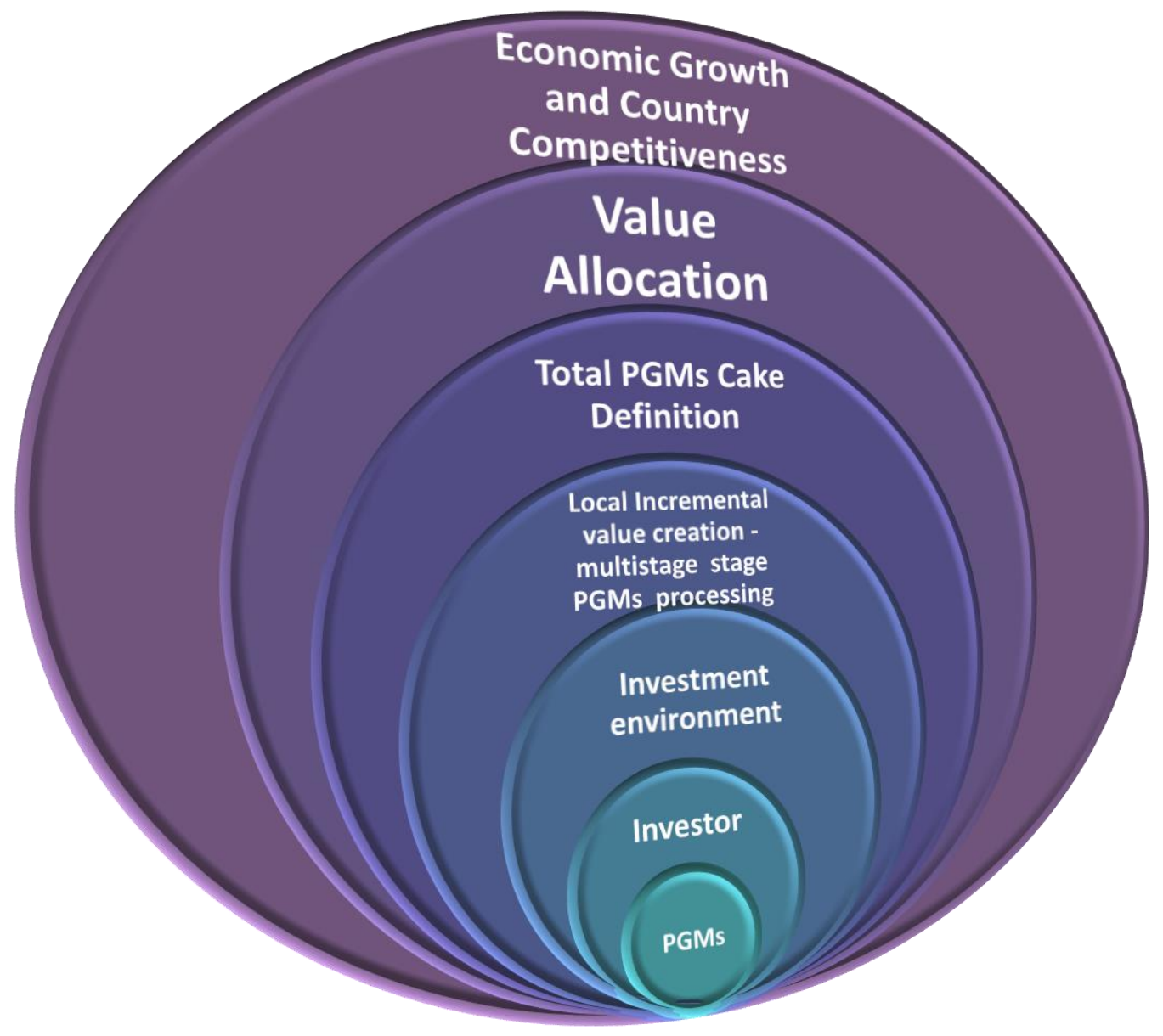

\section{CONCLUSION}

This paper establishes a direct correlation between an equitable investment environment and the sustainability of PGMs mining in Zimbabwe. The more favourable the conditions for profitability, the bigger the PGMs cake. Global best practice sustains the notion that national stakeholders derive their interest in supporting the growth of the PGMs sector broadly for their selfish reasons. These include the need for infrastructure development, value chain creation, employment and skills development, poverty reduction, business linkages and industrialisation.
The paper also buttresses the position of a nexus between rationale government policy and PGMs mining growth in Zimbabwe. Bad government policy shuts out globally reputable PGMs extractors and derails opportunities for backward and forward linkages, on its own an essential process for value addition and beneficiation. However, the dichotomy remains; whilst the country locates itself as the second largest holder of PGMs worldwide, only from South Africa, Zimbabwe misses a unique opportunity to increase PGMs exploitation, grow the PGMs sector, and create industries associated with the final products. The country only processes to matte, demonstrating that Zimbabwe cannot directly benefit from all products of the PGMs value chain. Zimbabwe, therefore, must recalibrate its PGMs 
exploitation matrix to enhance its chances of driving platinum global value chains from Zimbabwe and ensure the country becomes a global best practice in sustainable platinum mining and processing.

\section{REFERENCES}

[1] Hughes, C. (1970). Lateral Cryptic Variation in the Great Dyke of Rhodesia. Geological Magazine, 107(4), 319-325. doi:10.1017/S001675680005617X

[2] Stribrny, B., Wellmer, F., Burgath, K. et al. Unconventional PGE occurrences and PGE mineralisation in the Great Dyke: metallogenic and economic $\begin{array}{lllll}\text { aspects. } & \text { Mineral. Deposita 35, 260-280 (2000). }\end{array}$ https://doi.org/10.1007/s001260050019

[3] Fotoyi, A. (2020). Africa's Economic Transformation and Global Value Chains: An Analysis of the Platinum Value Chain in South Africa. Africa Development I Afrique Et Développement, 45(1), 163-180. doi:10.2307/26936569

[4] Gumede, V., \& Fadiran, D. (2019). Illicit Financial Flows in Southern Africa: Exploring Implications for Socio-economic Development. Africa Development / Afrique Et Développement, 44(2), 27-52. doi:10.2307/26873428

[5] Saunders, R. (2008). Crisis, Capital, Compromise: Mining and Empowerment in Zimbabwe. African Sociological Review / Revue Africaine De Sociologie, 12(1), 67-89. Retrieved October 30, 2020, from http://www.jstor.org/stable/24487552

[6] Stewart, P. (2013). Safer Underground Mining via Mechanisation? The case of South African gold and platinum mines. Labour, Capital and Society / Travail, Capital Et Société, 46(1/2), 116-138. Retrieved October 30, 2020, from http://www.jstor.org/stable/44706423
[7] Mujere, J. (2015). Insurgent citizenship and patterns of authority in mining affected areas: Understanding community protests in Rustenburg, South Africa. Labour, Capital and Society / Travail, Capital Et Société, 48(1\&2), 240-266. Retrieved October 30, 2020, from https://www.jstor.org/stable/26476425

[8] SIBINDI, N. (2020). (Rep.). South African Institute of International Affairs. doi:10.2307/resrep25950

[9] Capps, G. (2012). A bourgeois reform with social justice? The contradictions of the Minerals Development Bill and black economic empowerment in the South African platinum mining industry. Review of African Political Economy, 39(132), 315-333. Retrieved October 30, 2020, from http://www.jstor.org/stable/42003278

[10] Kotzé, L., \& Du Plessis, A. (2014). A Gold Rush to Nowhere? The Rightsbased Approach to Environmental Governance in South Africa's Mining Sector in Question. Verfassung Und Recht in Übersee / Law and Politics in Africa, Asia and Latin America, 47(4), 447-481. Retrieved October 30, 2020, from http://www.jstor.org/stable/43239754

[11] Stronski, P. (2019). Late to the Party: Russia's Return to Africa (pp. 23-32, Rep.). Carnegie Endowment for International Peace. doi:10.2307/resrep20998.9

[12] Mucciaroni, G. (1992). The Garbage Can Model \& the Study of Policy Making: A Critique. Polity, 24(3), 459-482. doi:10.2307/3235165

[13] Nyathi, T. (2016). An analysis of the implementation of the Indigenization Economic Empowerment policy in Zimbabwe.

\section{AUTHORS}

First Author - Oswell Binha, Africa University, College of Business Peace Leadership and Governance 